UDC: $\mathbf{3 5 1 . 8 5 1}$

DOI: https://doi.org/10.32689/2617-

2224-2020-1(21)-133-150

\section{Королюк Катерина Анатолї̈на,} студентка 3-го курсу кафедри сочіологї та політології Національного авіаційного університету, 03058, м. Київ, просп. Космонавта Комарова, 1, тел.: +38 (068) 791 82 17, e-mail: koroliuk.kate@outlook.com

ORCID: 0000-0002-5979-0874

Королюк Екатерина Анатольевна, студентка 3-го курса кафедры сочиологии и политологии Национального авиащионного университета, 03058, г. Киев, ул. Космонавта Комарова, 1, тел.: +38 (068) 791 82 17, e-mail: koroliuk.kate@outlook.com

ORCID: 0000-0002-5979-0874

Koroliuk Kateryna Anatoliiona, student of 3 course of the Department of Science and Sociology, National Aviation University, 03058, Kyiv, Prosp. Kosmonavta Komarova, 1, tel.: +38 (068) 79182 17, e-mail:koroliuk.kate@outlook.com
ORCID: 0000-0002-5979-0874

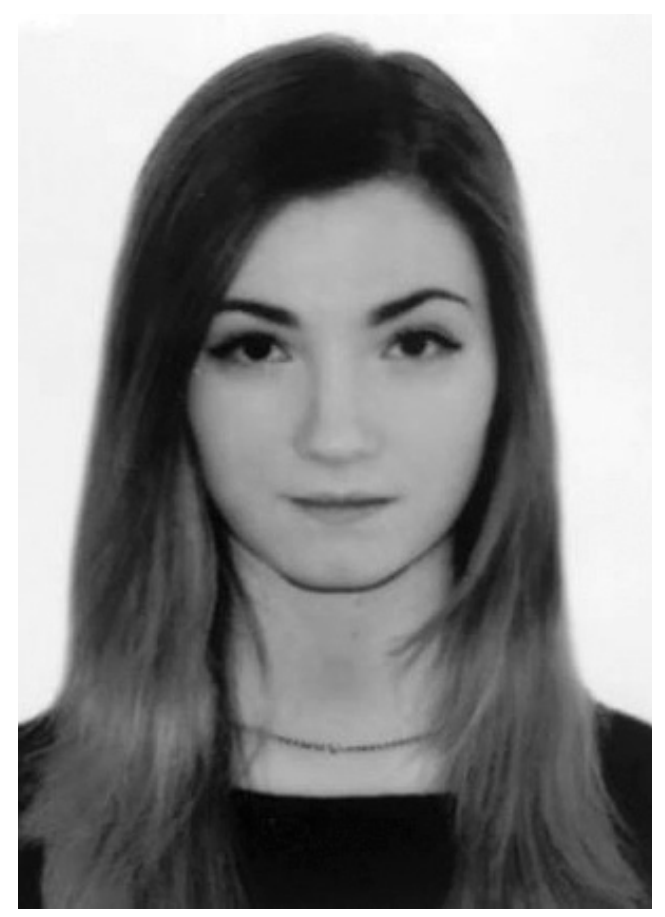

\title{
КОНЦЕПТУАЛЬНІ СХЕМИ РОЗВИТКУ СУЧАСНОЇ ДЕРЖАВИ (АРХЕТИПНИЙ ПІДХІД): КОНВЕРГЕНЦІЯ ТРАДИЦІЇ ТА ІННОВАЦІЇ
}

Анотація. Зазначено, що єдність нації - це стратегічний план безпеки і продуктивного розвитку сучасної держави, що в Україні формується поступово. 3’ясовано поєднання традицій та інновацій у сучасних підходах щодо розвитку держави як інституту, що забезпечує суспільний розвиток. Використано методи аналізу та синтезу, аналізу документів, знакове моделювання, компаративний (синхронний) аналіз. Було розглянуто коеволюційний етап розвитку суспільства та поняття індивідуального “Я” і колективного “Ми” як домінуючих суб'єктів соціальних інтеракцій на різних етапах одного циклу суспільного розвитку. Зміна традиційної концепції управління на нову втілюється у програмі діджіталізації (“Держава у смартфоні”) як засіб полегшення надання адміністративних послуг населенню. Яким саме є рівень готовності суспільства сприйняти ці зміни? Почуття спільної й особистої відповідальності - сприяе розвитку колективного “Ми”. Показано, 
що тенденції, які підтверджують позитивні зміни в Україні спостерігаються через виникнення багатьох волонтерських рухів, краудфандингових платформ, зростання кількості громадських організацій протягом останніх років. Разом з тим, зростає власна відповідальність індивіда за своє благополуччя. Чим розвиненішим є суспільство, тим активніше інновації впроваджуються у сферу суспільних відносин, значно оновлюючи їх. З’ясовано, що залученість громадян до суспільного сектору частково обумовлена публічним інтересом та тенденцією зростання попиту на зайнятість у публічному секторі і здійснення соціально значущої професійної діяльності. На основі здійсненого аналізу, було розроблено формулу, що прораховує індекс колективного “Ми”. Розуміння необхідності розвитку суспільства шляхом конвергенції традицій та інновацій - важлива частина у плануванні державної та соціальної політики України.

Ключові слова: коеволюція, трансформація, колективне “Ми”, архетипний підхід, сучасна держава, традиція, інновація.

\section{КОНЦЕПТУАЛЬНЫЕ СХЕМЫ РАЗВИТИЯ СОВРЕМЕННОГО ГОСУДАРСТВА (АРХЕТИПИЧЕСКИЙ ПОДХОД): КОНВЕРГЕНЦИЯ ТРАДИЦИИ И ИННОВАЦИИ}

Аннотация. Объединенность нации - это стратегический план безопасности и продуктивного развития современного государства, который в Украине формируется постепенно. Определено сочетание украинских традиций и инновации в современных подходах к развитию государства как института, обеспечивающего общественное развитие. Использованы методы анализа и синтеза, анализа документов, знаковое моделирование, компаративного (синхронного) анализа. Были рассмотрены коэволюционный этап развития общества и понятие индивидуального “Я” и коллективного “Мы” как доминирующих субъектов социальных интеракций на разных этапах одного цикла общественного развития. Современный украинский монопарламент, как он себя позиционирует, предлагает череду инноваций. Изменение традиционной концепции управления на новую воплощается в программе диджитализации (“Государство в смартфоне”) как средство облегчения предоставления административных услуг населению. Какой уровень готовности воспринимать эти изменения общества? Чувство общей и личной ответственности - способствует развитию коллективного “Мы”. Показано, что тенденции, которые подтверждают положительные изменения в Украине наблюдаются из-за возникновения многих волонтерских движений, краудфандинговых платформ, роста числа общественных организаций в последние годы. Вместе с тем повышается собственная ответственность индивида за свое благополучие. Чем более развитым является общество, тем активнее инновации внедряются в сферу общественных отношений, значительно обновляя их. Выяснено, что вовлеченность граждан в общественный сектор частично обусловлена публичным интересом и тенденцией роста спроса на занятость в публичном секторе и осуществления социально значимой про- 
фессиональной деятельности. На основе проведенного анализа, была разработана формула, что просчитывает индекс коллективного “Мы”. Понимание необходимости развития общества путем конвергенции традиций и инноваций - важная часть в планировании государственной и социальной политики Украины.

Ключевые слова: коэволюция, трансформация, коллективное "Мы”, архетипический подход, современное государство, традиция, инновация.

\section{CONCEPTUAL SCHEMAS OF MODERN STATE DEVELOPMENT (ARCHETYPAL APPROACH) CJNVERGENCE OF TRADITION AND INNOVATION}

Annotation. It was known that unity of the nation is a strategic safety plan and productive development of the modern state. In Ukraine, this process is formed gradually. The purpose of the article is to find out how Ukrainian traditions and innovations are combined in the modern approaches to the development of the state as an institute for social development.. The methods of analysis and synthesis, document analysis, sign modeling, comparative (synchronous) analysis are used in the work. It was regarded that co-evolutionary stage of state development and the concept of individual "I" and collective "We" as dominant subjects of social interaction at different stages of one cycle of social development.

Changing the traditional concept of governance is being implemented in the program of digitization ("State in a smartphone") as a means of facilitating the provision of administrative services to the population. What is the level of readiness to accept these changes in traditional society? A sense of common and personal responsibility contributes to the development of the collective "We". It was known trends that confirm positive changes in Ukraine are observed due to the emergence a lot of volunteer movements, crowdfunding platforms, an increasing a number of public organizations in recent years. At the same time, one's own responsibility for one's well-being is increased. The more developed the society, the more actively innovations are introduced into the sphere of social relations, significantly updating them. It has been found that public involvement in the public sector is partly driven by public interest and a growing demand for public sector employment and the pursuit of socially significant professional activity. Based on the analysis, a formula was developed that calculates the collective "We" index. Understanding the necessity of becoming a nation through the convergence of traditions and innovations is an important part in planning the Ukrainian state and social policy.

Keywords: co-evolution, transformation, collective "We", archetypal approach, modern state, tradition, innovation.

Постановка проблеми. Єдність нації - це стратегічний план безпеки і продуктивного розвитку сучасної держави, що в Україні формується 
поступово. Незважаючи на фактичну нерівність і експлуатацію, які панують, нація завжди сприймається як глибоке й солідарне братерство [1, с. 24]. Чи властиве воно українцям? Почуття спільної та особистої відповідальності - характерна риса для країн з розвиненою демократією. Ці тези важливо сьогодні застосувати для України, що знаходиться на шляху трансформації соціально-політичної свідомості свого народу від традиційності, питання лише в тому якою вона буде (трансформація).

ХХ століття завершилося під гуркіт збройних конфліктів, більшість 3 яких мали яскраві етнічні риси - на Балканах, у Центральній і Південній Азії, у Африці, навіть у Західній Свропі. Війни релігійного характеру (до XVIII ст.), війни імперій (XIX ст.), війни ідеологій (XX ст.) значною мірою сходять 3 авансцени історії. Вони уступають місце не зіткненням між державами чи наддержавами, а, швидше, конфліктам всередині держав - або по лініях цивілізаційних розломів всередині однієї держави або радикальній протестній активності соціального характеру, пов’язаній із поглибленням прірви між дуже багатими і дуже бідними (наприклад, рух “жовтих жилетів” у Франціi). Сучасне суспільство розвивається, прискорюючи рух у вузлах модернізаційних та state-трансформаційних конфліктів. Багато вчених мають підстави стверджувати про примусову ціннісну асиміляцію одних країн щодо інших, інші теоретизують полікультурність та концепти етнічного плюралізму як шлях запобігання протиріч складноструктурованого суспільства (challenges for variable society). Консервативні національні цінності втрачають зміст та актуальність, до них у своїх працях повертається чимраз менше сучасних дослідників. Актуальним стає образ супраглобальної людини, не диференційованої національно, культурно та релігійно, відкритої інноваціям та експерименту, такої, яка вміє швидко адаптовуватися до нових умов надзвичайно мінливого світу.

У даній роботі, використовуючи соціологічну концепцію нації (Д. Шнапер), ми спробуємо схарактеризувати тенденцію поєднання традиції та інновації у процесах розвитку сучасної держави в інформаційну епоху.

Аналіз останніх досліджень і публікацій. У ході дослідження було проаналізовано праці таких вітчизняних авторів: О. В. Суший, О. А. Донченко, Е. А. Афонін, А. Ю. Мартинов. Серед зарубіжних науковців: Б. Андерсон, І. Кішіловська та М. Кішіловський, А. Перотті, П. Штомпка, А. Етціоні, Т. Гоббс, Дж. Локк.

Мета статті: дослідити концептуальні схеми розвитку сучасних держав, з'ясувати, наскільки поєднуються традиції та інновації у процесі розбудови державного управління. У роботі були використані методи аналізу та синтезу, аналізу документів, знакове моделювання, компаративний (синхронний) аналіз. У даній роботі буде також проаналізовано коеволюційний етап розвитку українського суспільства; поняття індивідуального “Я” та колективного "Ми"; уточнено зміст понять "публічний сектор” i “публічний інтерес” та чому вони реактуалізуються в сучасному світі. 
Виклад основного матеріалу дослідження. Як стверджував Команданте Маркос у своїй праці "Четверта світова війна розпочалася”, що “у стриптиз-барі глобалізаціі” національна держава із своїм розмитим політичним обличчям вже майже цілком "роздягнулася", залишивши собі лише найнеобхіднішу функцію - функцію придушення. Відтак для національної держави метафора “нації” слугує символом в утилітарних цілях досягнення консолідації і загальної лояльності населення держави. Загальний дискурс про націю додає “додаткової” легітимності державній владі через створення образу, що остання є цілісною і здійснює управляння із іiї згоди (емоційна лояльність).

За Б. Андерсеном нація є специфічною уявленою спільнотою (imagines communities) - соціальним конструктом, члени якого не знають один одного і не взаємодіють між собою, але тим не менше розглядають себе як одну спільноту із загальним характером, надіями та долею [1, c. 35]. Вже сьогодні націю не можна обмежити територіальною чи мовною спільнотою (табл. 1). Можливо, завтра нею буде якась віртуальна спільнота користувачів, скажімо, певного типу програмування. I тоді їі адепти зможуть фізично перебувати у різних частинах світу, однак, у єдиній

\section{Поєднання традиції та інновації у теоретичному розумінні нації}

Таблиця 1

\begin{tabular}{|l|l|}
\hline \multicolumn{1}{|c|}{ традиційне розуміння нації } & \multicolumn{1}{|c|}{ Постсучасне розуміння нації } \\
\hline $\begin{array}{l}\text { 1. Людство природним чином } \\
\text { поділяться на нації }\end{array}$ & $\begin{array}{l}\text { 1. Нація стала лише однією із домінуючих } \\
\text { соціальних спільнот (соціально-культурні типи) }\end{array}$ \\
\hline $\begin{array}{l}\text { 2. Кожна нація має свій } \\
\text { самобутній характер. Нація } \\
\text { понад усе }\end{array}$ & $\begin{array}{l}\text { 2. Межі самобутності націй стали надзвичайно роз- } \\
\text { митими. Міфи про походження націй уже давно не } \\
\text { аксіомами }\end{array}$ \\
\hline $\begin{array}{l}\text { 3. Джерелом усієї політичної } \\
\text { влади є нація, колектив } \\
\text { в цілому }\end{array}$ & $\begin{array}{l}\text { 3. Джерелом усієї політичної влади є економічно } \\
\text { могутні транснаціональні компанії і репрезентована } \\
\text { ними глобальна, а не національна еліта }\end{array}$ \\
\hline $\begin{array}{l}\text { 4. Задля свободи й } \\
\text { самоздійснення люди повинні } \\
\text { ототожнювати себе з нацією }\end{array}$ & $\begin{array}{l}\text { 4. Привілеї, які надавала національна держава } \\
\text { через громадянство, нівельовано. Тепер без за- } \\
\text { ступнцтва національної еліти кожен досягає свого } \\
\text { статусу лише завдяки своїм професійним та осо- } \\
\text { бистим якостям, але за умови, що люди, із такими } \\
\text { розвиненими якостями користуються попитом на } \\
\text { світовому ринку праці }\end{array}$ \\
\hline $\begin{array}{l}\text { 5. Нації можуть зреалізувати } \\
\text { себе тільки у їхніх власних } \\
\text { державах }\end{array}$ & $\begin{array}{l}\text { 5. На сучасному етапі співдружність націй } \\
\text { реалізовують свої інтереси у різних міждержавних } \\
\text { об'єднаннях (наприклад: ЄС) }\end{array}$ \\
\hline $\begin{array}{l}\text { 6. Відданість нації-державі } \\
\text { перевершує інші відданості }\end{array}$ & $\begin{array}{l}\text { 6. Аксіологема відданості нації втратила свою } \\
\text { актуальність }\end{array}$ \\
\hline $\begin{array}{l}\text { 7. Найважливішою умовою } \\
\text { всесвітньої свободи й гармонії } \\
\text { є зміцнення національної } \\
\text { держави }\end{array}$ & $\begin{array}{l}\text { 7. Найважливішою умовою всесвітньої свободи } \\
\text { й гармонії є реалізація гедоністичних потреб } \\
\text { найбільшого числа індивідів }\end{array}$ \\
\hline
\end{tabular}


електронній мережі. Людська уява у концепції Б. Андерсона постає інструментом усвідомлення спільності членів великої групи (говорячи про “уявні” (але не придумані) спільноти, взято до уваги момент залучення).

Нація-держава у традиційних модерних теоріях завжди розглядається як основний суб'єкт міжнародних відносин, а національна еліта, репрезентована конкретними представниками певної нації - як єдиний фактичний учасник процесу творення політики. У глобальну епоху належність до нації сприймається конкретним індивідом як певний тягар, що позбавляє якості швидкої адаптації до мінливих умов глобалізованого світу, можливості у великих масштабах засвоювати транснаціональні цінності та мобільності як визначальної характеристики глобальної людини.

Ідеальний тип сучасного національного суспільства, який би грунтувався на цінностях, принципах та інститутах громадянства, намагалася змоделювати і викласти відомий соціолог Домінік Шнапер - дочка відомого вченого Раймона Арона. Нація як громадянська спільнота абстрактне політичне суспільство, що через інститут громадянства виходить за межі конкретних стереотипів, окремої відданості та соціальних нерівностей його членів. Адже усі люди, незалежно від свого історичного чи етнічно-релігійного походження та соціальних характеристик, - усі вони є громадянами. Звичайно, йдеться не про зображення об'єктивної реальності, а про формулювання принципу, на якому грунтується політичне право на жит- тя сучасних демократичних націй, іншими словами про “ідею” (в логічному розумінні) або ж про ідеальне політичне сьогодення. Саме це пояснює, що традиційне протиставлення між “етнічною” нацією або нацією “німецького” типу, з одного боку, i “громадянською спільнотою” або спільнотою “американського” типу, з другого боку, є історичним та ідеологічним, проте аж ніяк не аналітичним.

Формулювання цілого типу нації через вихід за етнічні реалії та соціальну нерівність за допомогою принципу громадянськості також дозволяє краще усвідомити суспільні реалії, ніж попередні бінарні історичні та ідеологічні концепції. Особистість та iii інтереси в сучасному світі посіли місце громадянина 3 його ідеалами. До Першої світової війни нація виступала засобом захисту та поваги до того, що в людині є по-справжньому людським, тобто iï незалежності, символом якої є рівність та свобода. Сучасний базис соціальних зв'язків береться під сумнів. Під час створення націй політика замінює релігійний чи династичний принцип об'єднання людей. I у будь-якій демократичній нації політика породжує соціальні проблеми.

Основна ідея монографії Д. Шнапер “Спільнота громадян” - надання певних інтелектуальних інструментів для пояснення логіки ідеї нації. Головна особливість нації полягає в об'єднанні населення у спільноту громадян, існування якого зумовлює внутрішню та зовнішню політику держави, процес перетворення спільноти громадян із абстрактного поняття у конкретну реальність (че- 
рез так звану інтегративну революцію (integrative revolution - термін К. Гірца).

Інновації у розвитку сучасних націй передбачають зокрема те, що кількість нових ролей та набутого (achieved) статусу громадян, що створюють націю, постійно збільшується на шкоду їх успадкованого (ascribed) статусу. Причому для створення нації як спільноти громадян за згаданою соціологічною концепцію важливим є наявність справжнього громадянського (публічного, суспільного) інтересу, який не завжди панує над особистими інтересами або інтересами окремої групи людей, але часто не залежить або не конфліктує з ними (тобто колективне “Ми” є дещо домінуючим над індивідуальним “Я”) [2, с. 156].

Відтак, активізачія потреби працювати над забезпеченням суспільного інтересу і розуміння суспільного як окремого та відмінного поняття $\epsilon$ важливим новим фактором розбудови сучасної (начіональної) держави. По-справжньому об'єднати людей можливо, лише запропонувавши їм певну кількість реальних підстав, цінностей та переваг, які в виправдали б неминуче колективне утворення та, можливо, потребуватимуть для його функціонування певної пожертви від окремих громадян. Залучити та забезпечити єдність можливо лише спільними діями сочіальних інститутів, завдяки яким покоління переймає звичку жити та співіснувати разом, властиве окремій історичній спільноті.

Отже, на цій підставі можна констатувати поєднання традиції та інновації. 3 одного боку, глобалізація неможлива без нарощування сил i потенцій національного життя (а це пряма функція національної держави. 3 іншого боку, сама глобалізащія додала начіональній державі принципово нову, раніше невідому функиію. У сучасному глобалізованому світі соціальна мобільність, яка отримала гігантські масштаби, інтенсивність комунікацій $i$ нерівність між краӥнами і народами створюють нові факти, умови $і$ основи відносин між групами, спільнотами людей. Іде активний розподіл і перерозподіл ролей, життєвих можливостей. Дискурс тепер не лише про те, наскільки неадекватно відчуває себе людина поза культурними національними кордонами, але особливо у тому, що в конкурентній боротьбі за життєві перспективи вона, як $і$ цілі колективи, не отримає виграшних ролей, якщо не буде спиратися на сили держави. Ось де загадка популярності сучасної національної держави та чому народи заради неї готові іти на жертви. Комплексне порівняння статусу нації-держави у модерну та постмодерну епоху зображене у табл. 2, 3.

Як бачимо, у минулому націоналізм національної держави пропонував нижчим класам статус та гідність, освіту і багато можливостей. Над національними державами на сучасному етапі нависають значні небезпеки. Ален Рено, намагаючись сформулювати ідею нової демократичної нації та подолати надто просте протиставлення між нацією-прагненням та нацією-спадщиною, запропонував новий термін “здібність до навчання”, як основну ідею нації, коли видима ознака наявності свободи у культурі та традиції нації полягає у здатності 
Концептуальні засади розвитку національної держави в модерну епоху (елементи традиціі)

\begin{tabular}{|c|c|c|c|c|}
\hline $\begin{array}{c}\text { Можливості } \\
\text { вищого класу }\end{array}$ & $\begin{array}{c}\text { Ризики } \\
\text { вищого } \\
\text { класу }\end{array}$ & $\begin{array}{c}\text { Можливості } \\
\text { нижчого класу }\end{array}$ & $\begin{array}{c}\text { Ризики } \\
\text { нижчого } \\
\text { класу }\end{array}$ & Глобалізація \\
\hline \begin{tabular}{|l|} 
- Створення нових \\
соціальних, еконо- \\
мічних та політич- \\
них можливостей, \\
заснованих на \\
детермінації наці- \\
ональних рамок. \\
• Захист від кон- \\
куренції ззовні. \\
• Можливість \\
використовувати \\
національний дис- \\
курс як своєрідну \\
культурну “ди- \\
мову завісу”, яка \\
покликана сховати \\
економічну екс- \\
плуатацію.
\end{tabular} & \begin{tabular}{|l|} 
• Розподіл ри- \\
зику із іншими \\
громадянами. \\
• Конкуренція \\
за ресурси і \\
владу всере- \\
дині країни.
\end{tabular} & $\begin{array}{l}\text { - Позиційні блага. } \\
\text { • Національна } \\
\text { гордість. } \\
\text { • Громадянство, } \\
\text { що залежить } \\
\text { від національ- } \\
\text { ної належності, } \\
\text { незалежно від } \\
\text { власності. } \\
\text { • Статус чи освіта. } \\
\text { - Політичні і соці- } \\
\text { альні права. } \\
\text { - Людська гід- } \\
\text { ність. } \\
\text { • Вихід на ринок, } \\
\text { освіта, мовні на- } \\
\text { вики, що полегшу- } \\
\text { ють мобільність. }\end{array}$ & $\begin{array}{l}\text { - Держава } \\
\text { загального } \\
\text { добробуту, } \\
\text { що робить } \\
\text { можливи- } \\
\text { ми загальні } \\
\text { ризики. }\end{array}$ & $\begin{array}{l}\text { - Ліберальний } \\
\text { прогресивний } \\
\text { націоналізм. } \\
\text { - Національна } \\
\text { держава ство- } \\
\text { рила баланс } \\
\text { інтересів } \\
\text { всіх класів, } \\
\text { що привів до } \\
\text { формування } \\
\text { міжкласової } \\
\text { коаліції. }\end{array}$ \\
\hline
\end{tabular}

Концептуальні засади розвитку національної держави в модерну епоху (елементи інноваціі)

\begin{tabular}{|c|c|c|c|c|}
\hline $\begin{array}{l}\text { Можливості } \\
\text { вищого класу }\end{array}$ & $\begin{array}{c}\text { Ризики } \\
\text { вищого } \\
\text { класу }\end{array}$ & $\begin{array}{c}\text { Можливості } \\
\text { нижчого класу }\end{array}$ & $\begin{array}{c}\text { Ризики } \\
\text { нижчого класу }\end{array}$ & Глобалізація \\
\hline 1 & 2 & 3 & 4 & 5 \\
\hline $\begin{array}{l}\text { - Держава більше } \\
\text { не хоче забезпечу- } \\
\text { вати такі можли- } \\
\text { вості, які індивіди } \\
\text { вважають для себе } \\
\text { безпечними. } \\
\text { - Глобальні мож- } \\
\text { ливості. } \\
\text { можливості. } \\
\text { • Обов'язки перед } \\
\text { нацією стають } \\
\text { тягарем. } \\
\text { Члени мобільних } \\
\text { класів тепер шу- } \\
\text { кають економічні } \\
\text { можливості у світі, } \\
\text { що знаходиться за } \\
\text { межами націо- } \\
\text { нальних горизон- } \\
\text { тів, а політичні }\end{array}$ & $\begin{array}{l}\text { • Держава } \\
\text { більше } \\
\text { не здатна } \\
\text { забезпечити } \\
\text { належний } \\
\text { захист. }\end{array}$ & $\begin{array}{l}\text { • Дефіцит } \\
\text { демократії. } \\
\text { • Системи } \\
\text { національної } \\
\text { освіти } \\
\text { стають менш } \\
\text { корисними. } \\
\text { • Націона- } \\
\text { льна мова стає } \\
\text { менш корисною } \\
\text { для набуття } \\
\text { професійних } \\
\text { навиків чи } \\
\text { мобілізації. }\end{array}$ & $\begin{array}{l}\text { • Логіку держави } \\
\text { всезагального } \\
\text { добробуту } \\
\text { стає все важче } \\
\text { забезпечити. } \\
\text { • Співробітни- } \\
\text { цтво між } \\
\text { поколіннями. } \\
\text { • Відкриті } \\
\text { кордони } \\
\text { руйнують } \\
\text { логіку держави } \\
\text { всезагального } \\
\text { добробуту і } \\
\text { послаблюють } \\
\text { можливості } \\
\text { поділяти ризики } \\
\text { між усіма } \\
\text { громадянами. }\end{array}$ & $\begin{array}{l}\text { • Держава } \\
\text { більше } \\
\text { не здатна } \\
\text { забезпечити } \\
\text { той же захист } \\
\text { і можливості, } \\
\text { що і в епоху } \\
\text { національної } \\
\text { держави. } \\
\text { - Розпад } \\
\text { міжкласової } \\
\text { коаліції } \\
\text { і поява } \\
\text { оборонного } \\
\text { агресивного } \\
\text { націоналізму. } \\
\text { • Оборонно- } \\
\text { регресивний } \\
\text { націоналізм } \\
\text { представляє }\end{array}$ \\
\hline
\end{tabular}


Закінчення табл. 3

\begin{tabular}{|c|c|c|c|c|}
\hline 1 & 2 & 3 & 4 & 5 \\
\hline $\begin{array}{l}\text { небезпеки глоба- } \\
\text { лізуються. Члени } \\
\text { цих класів праг- } \\
\text { нуть оптимізувати } \\
\text { корисність своїх } \\
\text { навиків і освіти. }\end{array}$ & & & $\begin{array}{l}\text { • Нижчі класи, } \\
\text { що залишені } \\
\text { наодинці } \\
\text { разом зі своїми } \\
\text { ризиками, } \\
\text { відчувають } \\
\text { спустошеність } \\
\text { (відтак, зростає } \\
\text { соціальна } \\
\text { напруга). } \\
\text { • Виникає } \\
\text { оборонний } \\
\text { націоналізм. у } \\
\text { своїй сильній, } \\
\text { етнорелігійній } \\
\text { формі він } \\
\text { є одним із } \\
\text { останніх } \\
\text { союзників } \\
\text { слабких та } \\
\text { наляканих } \\
\text { (реактуалізація } \\
\text { етнічності } \\
\text { та поява } \\
\text { неотрайбів). }\end{array}$ & $\begin{array}{l}\text { загрозу для } \\
\text { тих, хто бажає } \\
\text { піднятися } \\
\text { на хвилі } \\
\text { глобальних } \\
\text { змін. Для них } \\
\text { націоналізм - } \\
\text { це лише набір } \\
\text { спогадів, що } \\
\text { є тягарем. } \\
\text { Для всіх інших } \\
\text { громадян } \\
\text { націоналізм, } \\
\text { як і колись } \\
\text { раніше, } \\
\text { слугує } \\
\text { найбільш } \\
\text { підходящим } \\
\text { способом } \\
\text { розв'язання } \\
\text { соціально- } \\
\text { економічних } \\
\text { проблем. }\end{array}$ \\
\hline
\end{tabular}

людини навчитися цінностям цієї свободи та традиції (традиційний соціологічний термін “соціалізація”). Згідно з А. Рено, нація має сама навчитися прийнятно адаптовуватися до умов глобалізованого XXI століття. Ця точка зору повертає нас до архетипу “вічної дитини”, яка, між іншим, завжди відкрита до нового та бажає навчатися.

Ю. Хабермас свого часу запропонував поняття “конституційного патріотизму”, який на відміну від “умовної” форми національної сутності, не відповідає конкретній цілісності, а навпаки - конкретним процесам та принципам - громадянська та політична участь в національній ідентифікації [3, с. 238]. Патріотичне почуття пов'язується не $з$ країною як певною культурою та історичною нацією, а за державним принципом права. Люди приєднуються до принципів правової держави та до республіканського устрою, за виключенням будь-якого посилання на територію та певну історичну чи культурну спільноту. Кожна демократична держава була б в змозі надихнути патріотизм як необхідну умову збереження нації у глобалізованому світі. Окрім того, країнам, яким не економічними надпотугами у глобалізованому світі, потрібно знайти своє унікальне місце, можуть мати доволі вузький сектор чи спеціалізацію, своє know how (згідно футуристичної теорії досягнень - achievement theory). На нашу думку, сильна економіка, 
досягнута за рахунок спільного для всіх елементу господарства у вигляді загальнонаціональної корпорації, найкраще посилює почуття групової єдності, спільного інтересу та окремішності нації.

Проаналізуємо сучасний етап розвитку українського суспільства, який, зокрема, теоретиками Української школи архетипіки визначається як коеволюційний.

Традиційно термін коеволюція означає зростання співмірності, взаємозв'язків. За М. Моісеєвим, коеволюція - це гармонія між цілями людства та природою [4, с. 122]. Коеволюція є механізмом змін всередині системи. Вона (коеволюція) є фазовим переходом від нормативного періоду інволюції до нормативного періоду еволюції. Індикатором коеволюційного періоду $є$ справжній вибух індивідуальної активності [4, с. 209]. Підвищується власна відповідальність індивіда за своє благополуччя, посилюється потреба контролю за розвитком соціальних конфліктів, поступово визначальним чинником соціального життя стає якість інновацій [4, с. 145]. I чим

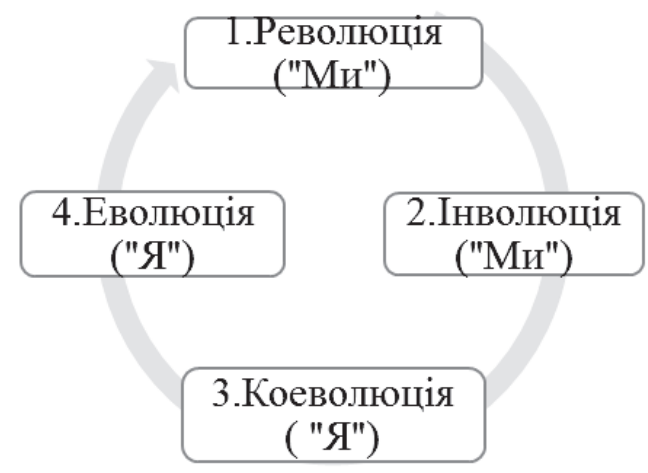

Цикл суспільного розвитку розвиненішим є суспільство, тим активніше інновації впроваджуються в сферу суспільних відносин. Порядок починає переважати над хаосом [4, с. 235]. Політична система активно перетворюється, впевнено вступає в силу суб’єкт “Я” (схема).

У перехідний коеволюційний період розвитку циклу виникають історичні передумови криз, коли починає змінюватися сама концепція управління [4, с. 212]. Економічний порядок трансформується в напрямі розширення свободи економічної діяльності [4, с. 145-147].

Саме зміну цієї концепції намагається демонструвати Україні новий парламент, що впроваджує програму діджіталізації або “Державу у смартфоні” як засіб полегшення надання адміністративних послуг населенню, що є звичною практикою для західноєвропейських країн. Однак, чи вдасться втілити цю реформу, всупереч архетипу (за К. Юнгом) обрядовості українців, що орієнтований на традиційні дії, відтворення сталих поведінкових практик, залишається відкритим питанням.

Президент Франції кінця 70-х рр. ХХ ст. Ж. Помпіду слушно наголошував, що державний діяч - це політик, який ставить себе на службу нації, а політик - це державний діяч, який ставить націю на службу собі. Потяг широких мас до модернізації може суперечити інтересам політичної еліти, яка контролює владу, тоді створюються передумови для появи нової еліти, яка починає реалізовувати накопичений інноваційний потенціал суспільства [4, с. 209]. Чи можна говорити про інноваційний потенціал українців? Відповідь - 
так. Прихід до влади “Зе” команди зумовлений власне необхідністю реалізації цього потенціалу. Рух країни до постіндустріального суспільства буде пов’язаний з приходом у велику політику молодого покоління українців [5, с. 93]. Власне, цей процес уже відбувся, адже “...Жодна інша сфера професійної діяльності не має такого великого потенціалу надавати людям можливості для значущої творчості та впливу, як державний сектор" [6, с. 22].

Залученість громадян до суспільного сектору частково обумовлена публічним інтересом та дедалі більшою зайнятістю у публічному сектоpi, що активно розвивається на Заході. Традиційна теза українців: “Моя хата скраю, нічого не знаю” поступово стає стереотипною і все рідше відповідає дійсності не лише через кордоцентризм, а й через бажання жити за спільними правилами.

M. Селігман перераховує три умови задоволення життям. Перша 3 них - наповненість сенсом, тобто необхідністю бути частиною чогось “більшого, ніж ви самі”. Друга - справжні стосунки з людьми. Третя - об'єктивні життєві досягнення [6, с. 339]. I для того, щоб реалізувати ці умови, бути “більшими, ніж ми самі” необхідне усвідомлення і розвиток колективного “Ми”. Цей процес в Україні, лише починає формуватися, позитивні тенденції якого можна спостерігати через виникнення багатьох волонтерських рухів, краудфандингових платформ, зростання кількості громадських організацій протягом останніх років. Якщо говорити про іноземний досвід, то прикладом вті- лення концепту колективного “Ми” стали президентські вибори 2016 p. у США, у яких здобув перемогу Д. Трамп. Американське суспільство створило запит на, певною мірою, відокремленість від решти світу, що переросло у політичне гасло передвиборчої кампанії 45-ого президента “Америка для американців” (план побудови стіни вздовж кордону 3 Мексикою, суворий контроль на в'їзд у США всім мусульманам, депортація певних груп населення, повернення додому американських військових, зменшення податків для населення). Результати політики Д. Трампа уже принесли свої плоди у вигляді стабільного зростання економіки протягом його президенства, а також зниження рівня безробіття.

Якщо в суспільстві, що стало на складний шлях розбудови нації, немає консолідаційно-інтеграційного смисло-дієвого ядра “навколо чогось”, то його заміщує антидієве ядро “проти чогось”, що стає чинником негативної консолідації [7, с. 4]. Можливо саме тому рівень громадянського суспільства значно зріс в 2014 році в Україні. Незадовільне соціальне самопочуття рано чи пізно навертає людей до певних дій, що мають на меті усунення "патології повсякденності”, а, отже, до збереження колективних уявлень, потреб і цінностей, що і є базисом самобутності [8]. Результатом недостатньої уваги з боку владних інститутів до населення було однією із причин акцій громадянського протесту під назвою “Свромайдан”.

Уявлені спільноти, описані в однойменній праці Б. Андерсона, фор- 
мують ідеї походження націоналізму, тобто ідеї утворення колективного "Ми". Національна приналежність уподібнюється до кольору шкіри, статі, родоводу й часу народження - тобто, до тих речей, які неможливо змінити [1, с. 180]. Це, власне, і детермінує загальну спільність на основі мови, культури, усталених практик поведінки. Концепт полікультурного суспільства мусить враховувати мовну і правову єдність, яка згладжує, а при потребі й обмежує культурні відмінності [9, с. 66]. Сформована наприкінці XX століття теорія комунітаризму А. Етціоні поєднувала соціальний обов'язок і соціальне благо, збалансовуючи при цьому цінності індивідуалізму із забезпеченням прав особистості та колективізму. Ї̈ лейтмотивом була свобода та рівність індивіда у взаємодї із поняттям суспільного блага та балансом між індивідуальною автономією $i$ порядком. Емансипаційна теорія демократії наголошує на особистій незалежності людини в суспільстві з дотриманням демократичних норм.

"Ми" - це гідність кожного окремого "Я". Value based public management (ціннісно-орієнтований підхід у публічному управлінні) гарантує це право. Поняття єдності або ж колективного "Ми" - парадоксально можливе лише при наявності декількох елементів, - це завжди сума чогось окремого, що взаємодіє.

Необхідність Bellum отпіuт contra oтпеs (війни всіх проти всіх), зникла вже давно, проте "суспільний договір” Т. Гоббса і Дж.Локка все ще має місце [10]. За ним, роль держави зводиться до гарантування іiї основних функцій - безпеки та регулювання відносин між людьми, які залишатимуться незмінними. Сама держава поступово спрощуватиметься, проте із зростанням самоорганізації суспільства. Внаслідок зростання індивідуальної активності $i$ відповідальності громадян, збільшуватиметься роль прямої демократії (наприклад, Brexit у Beликобританії, референдуми за незалежність у Шотландії та Каталоніі). Ця тенденція також має місце серед інших західноєвропейських країн та США. Так, приміром, у "Форбс" зазначається, що дедалі більше випускників престижних американських закладів освіти (підготовка магістрів із бізнес-адміністрування (МВА) відмовляються від добре оплачуваних робочих місць у приватних компаніях для роботи у суспільному секторі, аби зробити щось значуще, що матиме помітний вплив [6, с. 331]. Яскравим прикладом цієї тенденції стали результати президентських виборів України 2019 року. Тобто усвідомлення необхідності суспільної користі індивіда суспільству сприяє розвитку економіки і громадянського суспільства держави.

Коеволюція є механізмом змін всередині системи [4, с. 209]. Цей принцип поступово втілюється у реформі децентралізації влади в Украіні, що розпочалася у 2014 році та сприяла підвищенню рівня колективної відповідальності на місцях. Це свідчить про своєчасне намагання державою належно оцінити значний управлінський потенціал місцевого самоврядування та спро- 
можність вирішення проблем на місцях. Ефективність реформи певним чином доведена: так за даними Кабінету Міністрів України за останні 4 роки реформи створено 882 ОТГ, що об'єднали 4043 громади (36,7 \% від загальної кількості місцевих рад станом на 01.01.2015 року), це $38 \%$ території України і близько 69 \% населення [11].

Важко не погодитись із тезою, що управляти можна лише тим, що є вимірювальним [6, с. 305]. Місцева громада здатна краще оцінити успішність/провал реалізації реформ в межах своєї зони життєдіяльності, ніж уявляти, що було зроблено із запланованого представниками центральних органів влади. Тому вирі-

шення як локальних, так і глобальних проблем відбувається завдяки колективним зусиллям - так було завжди.

У ході дослідження на основі аналізу динаміки соціальних інтеракцій в українському суспільстві було розроблено формулу, за допомогою якої з'ясовано індекс колективного "Ми":

$$
\frac{(a+b) n}{r} \approx c,
$$

де $a$ - рівень індивідуальної активності, $b$ - колективної відповідальності, $n$ - кількість постійних соціальних зв'язків, $r$ - рівень пасивності, $c$ - індекс колективного "Ми" (табл. 4-7).

Таблиця 4

Показники змінних формули

\begin{tabular}{|l|l|l|l|}
\hline$a$ & $b$ & $n$ & $r$ \\
\hline 1 & 1 & 1 & 1 \\
\hline 2 & 2 & 2 & 2 \\
\hline 3 & 3 & 3 & 3 \\
\hline & & 4 & 4 \\
\hline & & 5 & 5 \\
\hline & & & 6 \\
\hline
\end{tabular}

Математичні обчислення дій

\begin{tabular}{|c|c|c|c|c|}
\hline $\mathrm{a}+\mathrm{b}$ & \multicolumn{5}{|c|}{$(a+b) \cdot n$} \\
\hline 2 & 2 & 8 & 16 & 30 \\
\hline 3 & 3 & 9 & 18 & \\
\hline 4 & 4 & 10 & 20 & \\
\hline 5 & 5 & 12 & 24 & \\
\hline 6 & 6 & 15 & 25 & \\
\hline
\end{tabular}


Значення змінних формули (на основі авторського соціологічного опитування громадян України, віком 18-35 років, вересень 2019 р., N - 112 осіб)

\begin{tabular}{|c|c|c|c|c|}
\hline № & $a$ & $b$ & $n$ & $r$ \\
\hline 1 & 2 & 3 & 4 & 5 \\
\hline 1 & $\begin{array}{l}\text { Не беру (не } \\
\text { брав) участі у } \\
\text { громадсько- } \\
\text { політичних } \\
\text { акціях, вважаю, } \\
\text { що держава } \\
\text { повинна } \\
\text { гарантувати } \\
\text { мені стандарти } \\
\text { якості життя на } \\
\text { високому рівні. }\end{array}$ & $\begin{array}{l}\text { Не займаюсь } \\
\text { жодною } \\
\text { волонтерською, } \\
\text { громадською } \\
\text { діяльністю. }\end{array}$ & $\begin{array}{l}\text { Щодня спілкуюсь з } \\
10 \text { і менше особами, } \\
\text { окрім членів сім'ї, } \\
\text { не маю лідерських } \\
\text { навичок. }\end{array}$ & $\begin{array}{l}\text { Щодня слідкую за } \\
\text { новинами і подіями } \\
\text { у світі, дотримуюсь } \\
\text { усіх законів без } \\
\text { винятку, виділяю } \\
\text { щонайменше } 10 \\
\text { год. в тиждень на } \\
\text { саморозвиток, } \\
\text { пропагую суспільно- } \\
\text { ціннісні ідеї, беру } \\
\text { участь у громадських } \\
\text { слуханнях, є } \\
\text { членом певних } \\
\text { волонтерських, } \\
\text { громадських } \\
\text { організацій. }\end{array}$ \\
\hline 2 & $\begin{array}{l}\text { Беру (брав) } \\
\text { участь у } \\
\text { волонтерських } \\
\text { рухах, гарно } \\
\text { навчаюсь/ } \\
\text { сум-лінно } \\
\text { працюю, маю } \\
\text { хобі, частково } \\
\text { відповідаю за } \\
\text { власні дії. }\end{array}$ & $\begin{array}{l}\text { Неодноразово } \\
\text { брав (ла) участь } \\
\text { у волонтерській, } \\
\text { громадській } \\
\text { діяльності. }\end{array}$ & $\begin{array}{l}\text { щодня спілкуюсь } 3 \\
20 \text { і менше особами, } \\
\text { окрім членів сім'ї. }\end{array}$ & $\begin{array}{l}\text { Намагаюсь постійно } \\
\text { слідкувати за } \\
\text { новинами своєї } \\
\text { країни, багаторазово } \\
\text { брав (ла) участь } \\
\text { у волонтерських } \\
\text { рухах, громадських } \\
\text { організаціях, } \\
\text { долучався(лась) до } \\
\text { вирішення суспільно- } \\
\text { важливих проблем, } \\
\text { регулярно займаюсь } \\
\text { підвищенням якості } \\
\text { власних знань. }\end{array}$ \\
\hline 3 & \begin{tabular}{|l|} 
Використовую \\
будь-які \\
ресурси для \\
самовдоскона- \\
лення, маю \\
лідерські \\
якості, а також \\
щонайменше \\
4 різні за \\
спрямованістю \\
види діяльності.
\end{tabular} & $\begin{array}{l}\text { Систематично } \\
\text { беру участь у } \\
\text { волонтерській, } \\
\text { громадській } \\
\text { діяльності або } \\
\text { є її членом, } \\
\text { регулярно } \\
\text { представляю } \\
\text { інтереси певних } \\
\text { суспільних груп, } \\
\text { мотивую інших } \\
\text { людей долучатись } \\
\text { до колективної } \\
\text { діяльності. }\end{array}$ & $\begin{array}{l}\text { Щодня спілкуюсь } 3 \\
30 \text { і менше особами, } \\
\text { окрім членів сім'ї, } \\
\text { серед яких люди } \\
\text { різного віку і } \\
\text { соціального статусу. }\end{array}$ & $\begin{array}{l}\text { Частково } \\
\text { задіяний(на) у } \\
\text { волонтерській, } \\
\text { громадській } \\
\text { діяльності, } \\
\text { іноді займаюсь } \\
\text { самоосвітою. }\end{array}$ \\
\hline
\end{tabular}


Закінчення табл. 6

\begin{tabular}{|c|c|c|c|c|}
\hline 1 & 2 & 3 & 4 & 5 \\
\hline 4 & & & $\begin{array}{l}\text { Щодня спілкуюсь } 3 \\
40 \text { і менше особами, } \\
\text { окрім членів сім'ї, } \\
\text { серед яких люди } \\
\text { різного віку і } \\
\text { соціального статусу } \\
\text { та серед яких є ті, } \\
\text { що знаходяться } \\
\text { безпосередньо } \\
\text { у моєму } \\
\text { підпорядкуванні. } \\
\end{array}$ & \begin{tabular}{|l} 
Частково \\
задіяний(на) \\
у суспільно- \\
громадській \\
діяльності, якщо це \\
стосується мене, \\
моєї сім'ї; маю хобі.
\end{tabular} \\
\hline 5 & & & $\begin{array}{l}\text { Щодня спілкуюсь } 3 \\
50 \text { і більше особами, } \\
\text { окрім членів сім'ї, } \\
\text { серед яких люди } \\
\text { різного віку і } \\
\text { соціального статусу } \\
\text { та серед яких є ті, } \\
\text { що знаходяться } \\
\text { безпосередньо } \\
\text { у моєму } \\
\text { підпорядкуванні } \\
\text { тає висококваліфі- } \\
\text { кованими } \\
\text { спеціалістами. }\end{array}$ & $\begin{array}{l}\text { Одно/дворазово } \\
\text { брав(ла)участь у } \\
\text { певних акціях, не } \\
\text { маю достатньо часу } \\
\text { на саморозвиток. }\end{array}$ \\
\hline 6 & & & & \begin{tabular}{|l} 
Ніколи не \\
брав(ла) участь \\
у волонтерських, \\
громадських \\
організаціях, \\
вважаю рівень \\
знань отриманих \\
під час навчання у \\
школі/університеті \\
достатнім для життя.
\end{tabular} \\
\hline
\end{tabular}

Індекс колективного "Ми"

Таблиця 7

\begin{tabular}{|c|c|c|c|c|c|c|c|}
\hline & \multicolumn{7}{|c|}{$(a+b) \cdot n / r$} \\
\hline 1 & \multicolumn{7}{|c|}{2} \\
\hline 2,00 & 3,00 & 4,00 & 5,00 & 6,00 & 8,00 & 9,00 & 10,00 \\
\hline 1,00 & 1,50 & 2,00 & 2,00 & 3,00 & 4,00 & 4,50 & 5,00 \\
\hline 0,67 & 1,00 & 3,00 & 1,67 & 2,00 & 2,67 & 3,00 & 3,33 \\
\hline 0,50 & 0,75 & 4,00 & 1,25 & 1,50 & 2,00 & 1,80 & 2,50 \\
\hline 0,40 & 0,60 & 0,80 & 1,00 & 1,20 & 1,60 & 1,50 & 2,00 \\
\hline 0,33 & 0,50 & 0,67 & 0,83 & 1,00 & 1,33 & 2,25 & 1,67 \\
\hline
\end{tabular}


Закінчення табл. 7

\begin{tabular}{|c|c|c|c|c|c|c|c|}
\hline 1 & \multicolumn{7}{|c|}{2} \\
\hline 15,00 & 12,00 & 16,00 & 18,00 & 20,00 & 24,00 & 25,00 & 30,00 \\
\hline 7,50 & 6,00 & 8,00 & 9,00 & 10,00 & 12,00 & 12,50 & 15,00 \\
\hline 5,00 & 4,00 & 5,33 & 6,00 & 6,67 & 8,00 & 8,33 & 10,00 \\
\hline 3,75 & 3,00 & 4,00 & 4,50 & 5,00 & 4,80 & 6,25 & 7,50 \\
\hline 3,00 & 2,40 & 3,20 & 3,60 & 4,00 & 4,00 & 5,00 & 6,00 \\
\hline 2,50 & 2,00 & 2,67 & 3,00 & 3,33 & 6,00 & 4,17 & 5,00 \\
\hline
\end{tabular}

Отже, з'ясовано, що найвищий показник колективного "Ми” - 30 досягнуто при умові найвищих показників індивідуальної активності, колективної відповідальності і постійних соціальних зв'язках, найменшому показникові пасивності, а найменший показник колективного “Ми” - 0,33 - при протилежному.

Висновки й перспективи подальших досліджень

“Якщо ви не знаєте, куди йдете, то можете опинитись десь не там, де треба", - зауважував Йогі Берра. Сьогодні в умовах надшвидких змін, Україні слід визначитись зі своїм соціально-культурно-політичним курсом, який зумовлений історично і ментально. Західні тенденції, що поглинають світ пропонують багато благ, питанням залишається чи інтеріоризує Україна зарубіжний досвід чи ще надовго залишатиметься поза суб'єктністю на світовій політичний арені. З'ясовано, що перспективним для України є напрям осмислення важливості ідеї колективного “Ми” та популяризації консолідації зусиль суспільства на забезпечення публічного інтересу. Це дещо контраверсує iз коеволюційним етапом розвитку українського суспільства наразі, але може чітко визначити мегатренди розбудови Української держави у найближчій перспективі. У практичній адміністратегіі, на нашу думку, також варто поєднати турботу про країну та їі інституції з цінуванням індивідуального успіху людей, які формують публічний сектор.

Динамічний процес розвитку колективного "Ми” в Україні, що розпочався після "Революції Гідності” сприяв виникненню багатьох волонтерських рухів, краудфандингових платформ, зростання кількості громадських організацій протягом останніх років. "У світі, де національна держава є загальною нормою, все це означає, що нації тепер можуть бути уявленими навіть і без мовної спорідненості...на підставі загального усвідомлення можливостей" [1, с. 169]. Цими можливостями для України є стрімкий розвиток економіки, підвищення соціально-демографічних показників. У найближчому майбутньому маємо підстави прогнозувати зростання тенденції самоорганізації суспільства, збільшення ролі прямої демократії, реактуалізацію індивідуальної активності і підвищення значущості громадянської відповідальності українців.

Коеволюція є механізмом змін всередині системи, яка не складається із простої суми змін окремих елементів. Усвідомлення необхідності 
суспільної користі індивіда суспільству прискорює розвиток громадянського суспільства держави. Сприяння процесу становлення нації шляхом конвергенції традицій та інновацій - важлива частина у плануванні державної та соціальної політики України.

Результати цієї роботи можуть бути використані як ідея для розробки майбутніх соціологічних теорій i прогнозів шляху розвитку України.

\section{СПИСОК ВИКОРИСТАНИХ} ДЖЕРЕЛ

1. Андерсон Б. Уявлені спільноти (міркування щодо походження й поширення націоналізму). Київ, 2001. 272 с.

2. Шнапер Д. Спільнота громадян. Харків, 2007. 223 с.

3. Штомпка П. Социология социальных изменений. Москва, 1996. 416 с.

4. Мартинов А. Ю. Історична соціологія (циклічна парадигма): монографія. Київ, 2004. 288 с.

5. Афонін Е. А., Бандурка О. М., Мартинов А. Ю. Велика розтока (глобальні проблеми сучасності: соціально-історичний аналіз): монографія. Київ: Парапан, 2002. 352 с.

6. Кішіловська І., Кішіловський М. Адмінстратегія. Київ, 2017. 368 с.

7. Суший О. В. Наукові студії із соціальної та політичної психології. Націєтворчий процес у координатах соцієтальної кризи в Україні. № 43 (46). Київ, 2019. С. 83-109.

8. Донченко О. Функції колективної психіки в державному управлінні. Веб-сайт URL: http://www.kbuapa. kharkov.ua/e-book/putp/2010-2/ doc/4/03.pdf.

9. Перотті А. Виступ на захист полікультурності. Львів, 2001. 128 с.

10. Гоббс Т. Левиафан, или Материя, форма и власть государства цер- ковного и гражданского. Москва: Мысль, 1991.

11. Реформа децентралізації. Веб сайт URL: https://www.kmu.gov.ua/diyalnist/reformi/efektivne-vryaduvannya/reforma-decentralizaciyi.

\section{REFERENCES}

1. Anderson, B. (2001). Ujavleni spiljnoty (mirkuvannja shhodo pokhodzhennja $\mathrm{j}$ poshyrennja nacionalizmu) [Imagined Communities (considerations for the origin and spread of nationalism)], Kyiv [in Ukrainian].

2. Shnaper, D. (2007). Spilnota hromadian [Community of citizens], Kharkiv [in Ukrainian].

3. Shtompka, P. (1996). Sociologija social'nyh izmenenij [Sociology of social change], Moskva [in Russian].

4. Martynov, A. (2004). Istorychna sociologhija (cyklichna paradyghma) [Historical Sociology (Cyclic Paradigm)]: monoghrafija, Kyiv, [in Ukrainian].

5. Afonin, E., Bandurka O. \& Martynov A. (2002). Velyka roztoka (ghlobaljni problemy suchasnosti: socialjno-istorychnyj analiz) [The Great Boredom (Global Problems of the Present: a Socio-Historical Analysis)]: monoghrafija, Kyiv: Parapan [in Ukrainian].

6. Kishilovsjka, I. \& Kishilovsjkyj, M. (2017). Administrateghija [Administration], Kyiv [in Ukrainian].

7. Sushyj, O. (2019). Nacijetvorchyj proces u koordynatakh socijetaljnoji kryzy v Ukrajini [The nation-building process in the coordinates of the social crisis in Ukraine], Scientific studies in social and political psychology, 43, 83109 [in Ukrainian].

8. Donchenko, O. (2010). Funkciji kolektyvnoji psykhiky $\mathrm{v}$ derzhavnomu upravlinni [Functions of the collec- 
tive psyche in public administration]. Retrieved from http://www.kbuapa. kharkov.ua/e-book/putp/2010 2/ doc/4/03.pdf [in Ukrainian].

9. Perotti, A. (2001). Vystup na zakhyst polikuljturnosti [Speech in defense of multiculturalism], Lviv [in Ukrainian].

10. Gobbs, T. (1991). Leviafan, ili Materija, forma i vlast' gosudarstva cerkovnogo i grazhdanskogo [Leviathan or The Matter, Forme and Power of a Common-Wealth Ecclesiasticall and Civil], Moskva: Mysl' [in Russian].

11. Reforma decentralizaciyi [Decentralization reform]. Retrieved from https://www.kmu.gov.ua/diyalnist/ reformi/efektivne-vryaduvannya/reforma-decentralizaciyi [in Ukrainian]. 